\title{
PELAKSANAAN PUTUSAN NOMOR: 1719/PDT.G/2018/PA.BWI DALAM PEMBAGIAN HARTA PERKAWINAN DALAM PERKARA POLIGAMI Oleh: Abdur Rohman
}

\author{
Program Magister Ilmu Hukum \\ Pascasarjana Fakultas Hukum Universitas Islam Malang \\ Jalan Mayjen Haryono No. 139 Malang
}

\begin{abstract}
Abstrak
Dapat dideskripsikan, bahwa pelaksanan pembagian harta gono-gini dalam perkawinan poligami adalah sama dengan pembagian harta gono-gini dalam perkawinan monogami, yaitu masing-masing pasangan mendapatkan bagian sama antara suami dan para istri, sebagaimana maksud Pasal 37 Undang-undang Nomor 1 Tahun 1974 dan Pasal 97 Kompilasi Hukum Islam. Ditetapkan harta bersama dalam perkara ijin poligami, adalah demi kemaslahatan dan melindungi Harta bersama Pemohon dan Termohon, agar istri yang baru tidak mengklaim harta bersama tersebut dengan menerapkan 3 pilar tujuan hukum yaitu keadilan, kemanfaatan dan kepastian hukum

Kata kunci: kepastian hukum, poligami, perkawianan
\end{abstract}

\section{Abstract}

It can be described, that the distribution of the gono-gini assets in the polygamy marriage is the same as the distribution of the gono-gini assets in a monogamous marriage, where each pair gets an equal share between husband and wife, as intended in Article 37 of Law Number 1 of 1974 and Article 97 Compilation of Islamic Law. Determined joint property in the case of a polygamy permit, is for the benefit and protection of Assets with the Petitioner and Respondent, so that the new wife does not claim the joint property by applying the 3 pillars of legal objectives namely justice, expediency and legal certainty

Keywords: legal certainty, polygamy, marriage

\section{PENDAHULUAN}

Agama Islam yang disyariatkan oleh Allah Ta'ala dengan ilmu-Nya yang maha tinggi serta hikmah dan ketentuan hukum-Nya yang maha agung, adalah agama yang sempurna aturan syariatnya dalam menjamin kemaslahatan bagi umat Islam serta membawa mereka meraih kebahagiaan hidup di dunia dan akhirat.

Pada dasarnya manusia mempunyai naluri/keinginan untuk mempunyai keturunan atau generasi. Dalam hal ini tentunya hal yang tepat untuk mewujudkanya adalah dengan melangsungkan perkawinan. Perkawinan merupakan salah satu cara membina hubungan sebuah keluarga, karena perkawinan mutlak diperlukan, dan menjadi syarat terbentuknya sebuah keluarga.

Sebuah perkawinan yang dimulai dengan adanya rasa saling cinta dan kasih sayang antara kedua belah pihak suami dan istri, akan senantiasa diharapkan berjalan dengan baik, kekal dan abadi yang didasarkan kepada Tuhan Yang Maha Esa. Hal ini sesuai pula dengan tujuan perkawinan itu sendiri berdasarkan Undang-Undang No.1 tahun 1974, bahwa perkawinan adalah ikatan lahir batin antara seorang pria dan seorang wanita sebagai suami istri degan tujuan membentuk keluarga (rumah tangga) yang bahagia dan kekal berdasarkan ke Tuhan Yang Maha Esa. 
Poligami merupakan suatu realitas hukum dalam masyarakat yang akhir-akhir ini menjadi suatu perbincangan hangat serta menimbulkan pro dan kontra. Poligami sendiri mempunyai arti suatu sistem perkawinan antara satu orang pria dengan lebih dari seorang istri. Pada dasarnya dalam Undang-Undang Perkawinan No. 1 Tahun 1974 tentang Perkawinan (selanjutnya disebut Undang-Undang Perkawinan) menganut adanya asas monogami dalam perkawinan. Hal ini disebut dengan tegas dalam Pasal 3 ayat (1) UndangUndang Perkawinan No. 1 Tahun 1974 tentang Perkawinan yang menyebutkan bahwa pada asasnya seorang pria hanya boleh mempunyai seorang istri dan seorang wanita hanya boleh mempunyai seorang suami.

Namun demikian, asas monogami dalam Undang-Undang Perkawinan No. 1 Tahun 1974 tentang Perkawinan tidak bersifat mutlak, artinya hanya bersifat pengarahan pada pembentukan perkawinan monogami dengan jalan mempersulit dan mempersempit penggunaan lembaga poligami dan bukan menghapus sama sekali sistem poligami.

Ketentuan adanya asas monogami ini bukan hanya bersifat limitatif saja, karena dalam Pasal 2 ayat (2) Undang-Undang Perkawinan disebutkan dimana pengadilan dapat memberikan izin pada seorang suami untuk beristri lebih dari seorang apabila dikehendaki oleh para pihak yang bersangkutan. Ketentuan ini membuka kemungkinan seorang suami dapat melakukan poligami dengan ijin pengadilan. Hal ini erat kaitannya dengan berbagai macam agama yang ada yang dianut oleh masyarakat karena ada agama yang melarang untuk berpoligami dan ada agama yang membenarkan atau membolehkan seorang suami untuk melakukan poligami. Khusus yang beragama Islam harus mendapat ijin dari pengadilan agama sesuai dengan Pasal 51 ayat (1) Kompilasi Hukum Islam dan yang beragama selain Islam harus mendapat ijin dari pengadilan negeri. Jadi hal ini tergantung dari agama yang dianut dan pengadilan yang berkompeten untuk itu.

Untuk mendapatkan ijin dari pengadilan harus memenuhi syarat-syarat tertentu disertai dengan alasan yang dapat dibenarkan. Tentang hal ini lebih lanjut diatur dalam Pasal 5 Undang-Undang Perkawinan dan Peraturan Pemerintah Nomor 9 Tahun 1975 tentang Pelaksanaan Undang-Undang Perkawinan No. 1 Tahun 1974 tentang Perkawinan.

Untuk beristri lebih dari satu orang dengan ketentuan jumlah istri dalam waktu yang bersamaan terbatas hanya sampai 4 orang. Adapun syarat utama yang harus dipenuhi adalah suami mampu berlaku adil terhadap istri-istrinya dan anak-anaknya, akan tetapi jika si suami tidak bisa memenuhi maka suami dilarang beristri lebih dari satu, di samping itu si suami harus terlebih dahulu mendapat ijin dari pengadilan agama, jika tanpa ijin dari pengadilan agama maka perkawinan tersebut tidak mempunyai kekuatan hukum.

Pengadilan agama baru dapat memberikan ijin kepada suami untuk berpoligami apabila ada alasan yang tercantum dalam Pasal 4 ayat (2) Undang-Undang Perkawinan:

1. Istri tidak dapat menjalankan kewajiban sebagai istri

2. Istri mendapat cacat badan atau penyakit yang tidak dapat disembuhkan

3. Istri tidak dapat melahirkan keturunan

Di samping syarat-syarat tersebut yang merupakan alasan untuk dapat mengajukan poligami juga harus dipenuhi syarat-syarat menurut Pasal 5 ayat (1) Undang-Undang Perkawinan, yaitu :

1. Adanya persetujuan dari istri

2. Ada kepastian bahwa suami mampu menjamin keperluan hidup istri dan anakanaknya

3. Ada jaminan bahwa suami berlaku adil terhadap para istri dan anak-anaknya. 
Mengenai persyaratan persetujuan dari istri yang menyetujui suaminya poligami dapat diberikan secara tertulis atau secara lisan akan tetapi sekalipun telah ada persetujuan tertulis dari istri persetujuan ini harus dipertegas dengan persetujuan lisan dari istri pada sidang Pengadillan Agama. Persetujuan dari istri yang dimaksudkan tidak diperlukan bagi suami apabila istri atau istri-istrinya tidak mungkin dimintai persetujuan dan tidak mungkin menjadi pihak dalam perjanjian dan apabila tidak ada khabar dari istrinya selama sekurangkurangnya 2 tahun atau karena sebab-sebab lainnya yang mendapat penilaian dari hakim Pengadilan Agama.

\section{PEMBAHASAN}

Pada asasnya dalam suatu perkawinan seorang pria hanya boleh mempunyai seorang istri, begitu juga dengan seorang wanita, namun dalam keadan tertentu lembaga perkawinan yang berasaskan monogami sulit dipertahankan.sehingga dalam keadaan yang sangat terpaksa dimungkinkan seorang laki-laki memiliki istri lebih dari seorang berdasarkan syarat-syarat yang telah ditentukan oleh Undang-Undang Perkawinan. Pasal 35 Undang-Undang Perkawinan mengatur tentang harta benda dalam perkawinan yaitu harta benda yang diperoleh selama perkawinan berlangsung menjadi harta bersama. Pasal 37 Undang-Undang Perkawinan menyatakan bila perkawinan putus karena perceraian, harta bersama diatur menurut hukumnya masing-masing, sedangkan di dalam Kompilasi Hukum Islam diatur apabila perkawinan putus karena perceraian, harta bersama dibagi antara suaml istri dengan pembagian yang sama. Dalam hal seorang laki-laki yang memiliki istri lebih dari seorang maka akan timbul suatu sengketa mengenai harta bersama tersebut, sehingga diperlukanlah suatu aturan yang jelas mengenai penetapan dan pembagian harta tersebut.

Berdasarkan Undang-Undang yang ada penyelenggaraan kekuasaan kehakiman diserahkan kepada badan-badan peradilan yang ditetapkan dengan Undang-Undang. Peradilan adalah kekuasaan Negara dalam menerima, memeriksa, mengadili, memutus dan menyelesaikan perkara untuk menegakkan hukum dan keadilan. ${ }^{1}$

Meskipun demikian, hal itu tidak mengurangi makna dan penerapan hukum yang berkenaan dengan harta yang diperoleh suami-isteri selama perkawinan. Harta tersebut melembaga menjadi harta bersama antara suami-isteri, selama ikatan perkawinan masih berlangsung tanpa mempersoalkan suku dan stelsel keluarga suami-isteri. ${ }^{2}$ Umumnya setiap pasangan suami istri mendambakan terciptanya rumah tangga yang sakinah mawadah warahmah. Salah satu faktor penunjang terwujudnya rumah tangga yang sesuai dengan konsep Islam ini adalah sebuah harta kekayaan yang merupakan Zinatul al- hayat, baik harta yang bergerak maupun harta yang tidak bergerak, bahkan termasuk di dalamnya surat-surat berharga dan intelektual, dikarenakan kekayaan harta bersama itu berperan sebagai pelengkap kebahagiaan. Namun, Apabila rumah tangga mengalami kondisi disharmonis maka adanya kemungkinan timbul adanya perselisihan dan pertengkaran yang cukup besar atau tidak dapat di atasi (out of control), kemungkinan besar peluang kondisi rumah tangga mengarah pada kondisi bubarnya perkawinan (broken marriagge).

Pada tataran terakhir, harta bersama akan menjadi ajang persengketaan. Dan tidak dapat dipungkiri lembaga peradilan pun akan cukup berperan dalam proses penyelesaian

\footnotetext{
${ }^{1}$ Cik Hasan Bisri, Peradilan Agama di Indonesia (Jakarta: PT Raja Grafindo Persada, 1998),

${ }^{2}$ Yahya Harahap, Kedudukan dan Kewenangan dan Acara Peradilan Agama (Jakarta: Sinar Grafika, 2009), Hal. 272
} 
persengketaan yang dimaksudkan di atas. Lembaga peradilan akan menjadi media bagi suami istri yang bersengketa untuk menuangkan semua argumentasi dan unek-unek mereka, lebih khususnya dalam rangka mewujudkan keinginan masing-masing para pihak untuk menguasai harta tadi. Dengan demikian, adanya KHI tersebut semua produk hukum yang keluar dari lingkungan peradilan agama harus berpedoman dan mengacu pada Undang-Undang No. 1 Tahun 1974 dan KHI dan dalam proses beracaranya berpedoman pada hukum acara peradilan agama. Berdasarkan pasal 86 ayat (1) hukum acara peradilan agama menyebutkan bahwa penetapan harta bersama hanya bisa dibagi ketika ada perceraian dan permohonan mengenai pembagian harta bersama suami istri hanya dapat diajukan bersama-sama dengan gugatan perceraian ataupun sesudah putusan perceeraian memperoleh kekuatan hukum tetap. Sedangkan berdasarkan pra survey dalam perkara ijin poligami Pengadilan Agama Banyuwangi dalam putusan perakara permohonan izin poligami Hakim Pengadilan Agama Banyuwangi dengan pertimbangan hukumnya mengabulkan penetapan pembagian harta bersama tanpa ada perceeraian. Sehingga penulis tertarik untuk memilih putusan Pengadilan Agama Banyuwangi untuk dijadikan objek penelitian dalam tesis ini.

Pasal 35 UU perkawinan ayat (1) menyebutkan: Harta bersama adalah harta benda yang diperoleh selama perkawinan menjadi harta bersama. ${ }^{3} \mathrm{M}$. Idris Ramulya mendefinisikan harta bersama adalah barang yang menjadi kekayaan yang diperoleh sesudah mereka berada dalam hukum perkawinan berlangsung atas usaha mereka berdua atau usaha salah seorang dari mereka. ${ }^{4}$

Sampai sekarang, penggunaan berbagai macam istilah tersebut masih mewarnai praktek peradilan. Meskipun Pasal 35 UU No. 1 Tahun 1974 sudah memberi istilah yang harus dibakukan dalam kehidupan hukum dan peradilan, kesatuan istilah belum tercapai. Namun demikian, hal itu tidak mengurangi makna dan penerapan hukum yang berkenaan dengan harta yang diperoleh suami-isteri selama perkawinan.

Menurut Pasal 1 huruf (f) Kompilasi Hukum Islam menyebutkan bahwa harta kekayaan dalam perkawinan atau syirkah adalah harta yang diperoleh, baik sendiri-sendiri atau bersama suami-isteri selama ikatan perkawinan berlangsung dan selanjutnya disebut harta bersama, tanpa mempersoalkan terdaftar atas nama siapapun.

UU Perkawinan No. 1 tahun 1974 mengatur harta kekayaan dalam perkawinan di dalam Bab VII Pasal 35, Pasal 36 dan Pasal 37.

Bunyi Pasal 35 yaitu:

(1) Harta benda diperoleh selama perkawinan menjadi harta bersama

(2) Harta bawaan dari masing-masing suami dan istri dan harta benda yang diperoleh masing-masing sebagai hadiah atau warisan adalah dibawah pengguasan masing-masing sepanjang para pihak tidak menentukan lain.

Bunyi Pasal 36 yaitu:

(1) Mengenai harta bersama suami atau istri dapatlah bertindak atas persetujuan kedua belah pihak.

${ }^{3}$ Siti Musdah Mulia,Posisi Perempuan dalam Hukum Islam di Indonesia,(Jakarta: Kencana, 2008), hal.134

${ }^{4}$ M. Idris Ramulya, Hukum Pekawinan, Hukum Pewarisan, Hukum Kewarisan, Hukum Acara Peradilan Agama, (Jakarta: Sinar Grafika, 1995), hal. 29

${ }^{5}$ H.M.A. Tihami, , Fikih Munakahat (Jakarta: PT.Raja Grafindo Persada, 2008), Hal. 179. 
(2) Mengenai harta bawaan masing-masing, suami dan istri mempunyai hak sepenuhnya untuk melakukan perbuatan hukum mengenai harta bendanya.

Bunyi Pasal 37 yaitu:

Bila perkawinan putus karena perceraian, harta bersama diatur menurut hukumnya masing-masing.

Aturan-aturan pasal tersebut pada dasarnya telah memberikan gambaran yang cukup jelas. Apabila dianalisis lebih lanjut ternyata ungkapan pada pasal 37 undangundang perkawinan ini tidak memberikan keseragaman hukum positif tentang bagaiman penyelesaian dan pembagian harta bersama apabila terjadi perceraian.

Menurut pasal 24 ayat (2) huruf c PP No. 9 Tahun 1975 selama berlangsungnya gugatan perceraian atas permohonan penggugat atau tergugat atau berdasarkan pertimbagan bahaya yang mungkin timbul, pengadilan dapat mengizinkan dan menentukan hal-hal yang perlu untuk menjamin terpeliharanya barang-barang yang menjadi hak bersama suami istri. Dari segi redaksi, ketentuan ini lebih tegas dari pasal 190 KUH Perdata. Karena di dalamnya terdapat perkataan menjamin terpeliharanya harta bersama. Namun terlepas dari itu, hampir tidak ada perbedaan antara keduanya. Sama-sama bermaksud mengamankan keberadaan dan keutuhan harta bersama agar tidak jatuh kepada pihak ketiga. ${ }^{6}$

Untuk menjamin keutuhan dan keselamatan harta bersama selama proses perkara berlangsung, hanya dengan cara meletakkan sita marital di atasnya. Ditinjau dari segi penjaminan keberadaan harta bersama dalam perkara pembagian harta bersama, sangat urgen meletakkan sita marital selama proses pemeriksaan berlangsung. Oleh karena itu sangat relevan menerapkan sita marital dalam perkara pembagian harta bersama. Dalam putusan Mahkamah Agung tanggal 9 November 1976 No.1448 K/Sip/1974. Dalam putusanya ini ditegaskan "sejak berlakunya UU No.1 Tahun 1974, harta benda yang diperoleh selama perkawinan menjadi harta bersama, sehingga pada saat terjadinya perceraian harta bersama tersebut dibagi sama rata antara bekas suami istri. "“

Harta bersama itu dibuka pembagiannya jika terjadi perceraian dan apabila tidak adanya perceraian maka harta bersama itu tidak bisa dibagi tetapi hanya bisa disita saja, harta bersama antara suami istri baru dapat dibagi apabila hubungan perkawinan itu sudah terputus. Hubungan perkawinan itu dapat terputus karena kematian, perceraian dan dapat juga oleh keputusan pengadilan. ${ }^{7}$ Sedangkan permohonan ijin poligami bukanlah perkara perceraian.

\section{PENUTUP}

Pelaksanan pembagian harta gono-gini dalam perkawinan poligami adalah sama dengan pembagian harta gono-gini dalam perkawinan monogami, yaitu masing-masing pasangan mendapatkan bagian sama antara suami dan para istri, sebagaimana maksud Pasal 37 Undang-undang Nomor 1 Tahun 1974 dan Pasal 97 Kompilasi Hukum Islam. Ditetapkan harta bersama dalam perkara ijin poligami, adalah demi kemaslahatan dan melindungi Harta bersama Pemohon dan Termohon, agar istri yang baru tidak mengklaim harta bersama tersebut dengan menerapkan 3 pilar tujuan hukum yaitu keadilan, kemanfaatan dan kepastian hukum.

\footnotetext{
${ }^{6}$ M. Yahya Harahap, Hukum Acara Perdata (Jakarta: Sinar Grafika, 2011), hal. 370

${ }^{7}$ Idris Ramulyo, Hukum Perkawinan ,Hukum Kewarisan,Hukum Acara Peradilan Agama dan Zakat Menurut Hukum Islam, (Jakarta: Sinar Grafika,1995), hal. 35-36.
} 


\section{DAFTAR PUSTAKA}

\section{BUKU}

Basyir, Ahmad Azhar. 1978. Hukum Perkawinan Islam, Fakultas Hukum Universitas Indonesia, Yogyakarta.

Ramulya M. Idris. 1995. Hukum Pekawinan, Hukum Pewarisan, Hukum Kewarisan, Hukum Acara Peradilan Agama, Sinar Grafika, Jakarta.

Soekanto Soerjono. 1986. Pengantar Penelitian Hukum, Cetakan 2, Universitas Indonesia, Jakarta.

Waluyo Bambang. 1991. Penelitian Hukum Dalarn Praktek, Sinar Grafika, Jakarta.

Yahya Harahap. 2009. Kedudukan dan Kewenangan dan Acara Peradilan Agama, Jakarta.

\section{Peraturan Perundang-Undangan}

Undang-undang RI nomor 1 tahun 1974 tentang Perkawinan dan Kompilasi Hukum

Islam, (Citra Umbara: bandung, 2010),hal 267

Undang-Undang Nomor 1 Tahun 1974 tentang Perkawinan

Peraturan Pemerintah Nomor 9 Tahun 1975 tentang Pelaksanaan Undang-Undang Nomor 1 Tahun 1974 tentang Perkawinan

Instruksi Presiden Nomor 1 Tahun 1991, tentang Penyebarluasan Kompilasi Hukum Islam. 